\title{
Cockle shell-derived aragonite calcium carbonate nanoparticle for targeting cancer and breast cancer stem cells
}

\author{
Kehinde Muibat Ibiyeye ${ }^{\text {*}^{*}}$, Sherifat Banke Idris ${ }^{2}$ and Abu Bakar Zakaria Zuki ${ }^{2^{*}}$
}

\author{
*Correspondence: \\ kehindebiyeye@gmail.com; \\ zuki@upm.edu.my \\ ${ }^{1}$ Laboratory of Molecular \\ Biomedicine, Institute \\ of Bioscience, Universiti Putra \\ Malaysia, Selangor, Malaysia \\ 2 Department of Veterinary \\ Preclinical Sciences, Faculty \\ of Veterinary Medicine, \\ Universiti Putra Malaysia, \\ Selangor, Malaysia
}

\begin{abstract}
Cockle shell-derived aragonite calcium carbonate nanoparticles (CACNP) have demonstrated prospect as nano-sized drug carriers for targeting cancer cells. CACNP is biocompatible, biodegradable and its biomaterial is readily available and is of low cost. In addition, CACNP is highly porous, has a large surface area which confer a high loading capacity. The $\mathrm{pH}$-dependent release properties as well as its potential for surface functionalization with targeting agents make CACNP useful in passive and active targeting of cancer cells and cancer stem cells. In this article, we reviewed the current state of CACNP as nano-sized drug carrier for targeting cancer cells, cancer stem cells and its biocompatibility.
\end{abstract}

Keywords: Calcium carbonate nanoparticle, Cockle shell, Biocompatibility, Cancer therapy

\section{Introduction}

Cancer arises from multiple mutations in the genome which results in interruption in the normal cellular homeostasis. This disruption in cellular homeostasis drives normal cells to acquire a succession of hallmark capabilities that allow them to become tumorigenic and eventually malignant. These hallmark capabilities include replicative immortality, genomic instability, evasion of growth suppression, resisting cell death, sustained proliferation, altered metabolism, avoiding immune destruction, use tumour promoting inflammation to their advantage, angiogenesis induction, activation of process of invasion and metastasis. Continuous uncontrolled replication results in colony of abnormal cells which are heterogeneous in nature; interacting with each other and the extracellular component (Hanahan and Weinberg 2000, 2011; Sancho et al. 2016). The efficacy of conventional chemotherapeutic agent is limited by systemic toxicity and multidrug resistance. Nonetheless significant progress has been made in the field of nanotechnology to overcome these problems, thus offering promising and effective alternatives for cancer treatment (Blanco et al. 2015). Nanotechnology has shown a great advantage in drug delivery for cancer treatment by enhancing build-ups of cytotoxicity in tumour tissue, specificity in tumour targeting, reducing the cytotoxic side effects on normal cells,

(C) The Author(s) 2020. This article is licensed under a Creative Commons Attribution 4.0 International License, which permits use, sharing, adaptation, distribution and reproduction in any medium or format, as long as you give appropriate credit to the original author(s) and the source, provide a link to the Creative Commons licence, and indicate if changes were made. The images or other third party material in this article are included in the article's Creative Commons licence, unless indicated otherwise in a credit line to the material. If material is not included in the article's Creative Commons licence and your intended use is not permitted by statutory regulation or exceeds the permitted use, you will need to obtain permission directly from the copyright holder. To view a copy of this licence, visit http://creativecommons.org/ licenses/by/4.0/. The Creative Commons Public Domain Dedication waiver (http://creativecommons.org/publicdomain/zero/1.0/) applies to the data made available in this article, unless otherwise stated in a credit line to the data. 
reducing systemic side effect, increasing drug solubility, and increasing maximum tolerated dose.

Cockle shell-derived aragonite calcium carbonate nanoparticles (CACNP) have demonstrated prospect as nano-sized drug carriers for targeting cancer cells. CACNP is biocompatible, biodegradable and its biomaterial is readily available and is of low cost. In addition, CACNP is highly porous, has a large surface area which confer a high loading capacity. The $\mathrm{pH}$-dependent release properties as well as its potential for surface functionalization with targeting agents make CACNP useful in passive and active targeting of cancer cells and cancer stem cells. Hence, this article reviews the available literatures on CACNP as drug delivery system for targeting cancer cells (Mailafiya 2019a).

\section{Calcium carbonate nanoparticles}

$\mathrm{CaCO} 3$ is an important industrial mineral that is used in most sphere of human life (Horie 2014; Lauth et al. 2017). The characteristic high surface area and small size favours its use in food, paint, rubber, cosmetic, cement and stationary industries (Horie 2014). Six crystal morphologies of $\mathrm{CaCO}_{3}$ has been reported namely; calcite, vaterite, aragonite, amorphous calcium carbonate, ikaite and monohydrocalcite (Lauth et al. 2017). Anhydrous $\mathrm{CaCO}_{3}$ has three polymorphs-calcite, vaterite and aragonite (Fig. 1), which have been tried for controlled drug delivery (Lauth et al. 2017). The calcite polymorph exists as trigonal crystalline form in nature while the aragonite and vaterite polymorphs are seen as orthorhombic and hexagonal systems, respectively (Dizaj et al. 2015). The polymorphs can be differentiated based on spatial arrangement of the calcium and carbonate ions which determines their stability and solubility (Mydin et al. 2018; Dizaj 2015). Calcite is the most thermodynamically stable and least soluble in water followed by aragonite (Boulos (2014); Kezuka et al. 2017). Vaterite on the other hand, is the least stable and most soluble in water (Boulos (2014)). The vaterite polymorph easily changes to either aragonite at $30^{\circ} \mathrm{C}$ or calcite at $60-80{ }^{\circ} \mathrm{C}$ (Boulos 2014; Li et al. 2019). The three polymorphs can be found simultaneously in some types of molluscs and sea algae, but calcite and aragonite are more common (Ni and Ratner 2008).

Recently, the fabrication and therapeutic application of $\mathrm{CaCO}_{3}$ nanoparticles in drug delivery has generated a lot of attention amongst scientists due to its availability, ease of synthesis, low toxicity and slow biodegradability (Mydin et al. 2018; Dizaj 2015; Li et al. 2019). $\mathrm{CaCO}_{3}$ nanoparticles have been synthesized using various methods including wet chemical preparation, microemulsion technique and mechanical milling of sea and egg

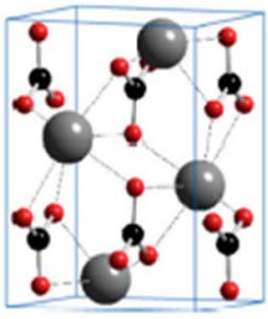

Aragonite

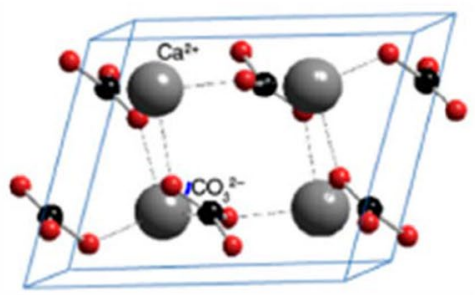

Calcite

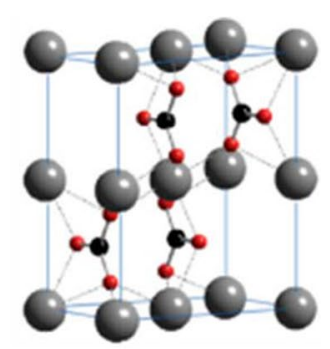

Vaterite

Fig. 1 Crystalline structures of calcium carbonate (modified from Yan et al. 2016) 
shells (Mydin et al. 2018; Dizaj 2015; Ranjan et al. 2018). Ghiasi and Malekzadeh (2012) used the sol-gel citrate method to synthesize calcite nanoparticles by adding organic additives as emulsifiers. The main advantage of this citrate method is that it lowers the calcination temperature (Ghiasi and Malekzadeh 2012). $\mathrm{CaCO}_{3}$ nanoparticles have also been synthesized by thermolysis of a precursor molecule, calcium oxalate-a low-cost method that can be used for bulk production of calcium carbonate nanoparticles (Ranjan et al. 2018). Monodispersed $\mathrm{CaCO}_{3}$ nanoparticles was synthesized using batch carbonation process with ultrasonication (He et al. 2005). The advantage of this method is that it produced $\mathrm{CaCO}_{3}$ nanoparticles of small and narrow size distribution (He et al. 2005). The use of natural reserves of calcium carbonate such as egg shells and cockle shell to synthesize $\mathrm{CaCO}_{3}$ nanoparticles is advantageous because it is readily available, non-toxic, and biocompatible as well as manage wastes from processing these foods as such this makes ideal candidates for biomedical applications (Render 2016; Idris et al. 2019).

\section{Cockle shell-derived aragonite calcium carbonate nanoparticle}

One of the most important considerations for nanoparticle design is the safety of the delivery system. The materials for designing nanoparticle must be biodegradable, biocompatible and should not produce toxic by-products (Vishwakarma et al. 2010; Wolfram 2015). In addition, nanoparticle should have high drug-loading capacity with maximum drug release from the particle at the tumour site and the surface charge of the nanoparticle must be within the stability range $>25 \mathrm{mV}$ and $<-25 \mathrm{mV}$ (Honary and Zahir 2013a, b). The size of the nanoparticle needs to be optimal for systemic administration. Too large particles result in embolus formation while particles less than $10 \mathrm{~nm}$ are rapidly cleared from the circulation. The nanoparticle size range of $50 \mathrm{~nm}$ to $100 \mathrm{~nm}$ showed enhanced passive targeting by the EPR effect (Xu et al. 2015). The production of the nano-sized particle should be simple and allows for scale-up.

Cockle shell-derived aragonite calcium carbonate nanoparticle (CACNP) has a promising potential and it is an ideal nanomaterial for drug delivery due to its higher surface area, surface structural porosity with large loading content capacity, $\mathrm{pH}$-dependent drug release, biocompatible and biodegradable (Mailafiya 2019a). The preparation of CACNP involves top down mechanical milling and/ or the use of BS-12; a simple synthesis method to produce large-scale nanoparticles that is cost effective and utilize the natural abundance of cockle shell (Xu et al. 2015). CACNP has also been prepared by dissolution precipitation method (Tram 2020) and higher pressure homogenizer microemulsion technique (Kamba 2013). The structural surface porosity CACNP encourages the incorporation of both hydrophilic and hydrophobic drugs with increase drug loading and encapsulation efficiency (Mailafiya 2019a).

CACNP appears as rod-to-spherical when observed with transmission electron microscopy (TEM). Both pleomorphic and homogeneous surface morphology under field emission scanning electron microscopy (FESEM) has been described. The size ranges from 11 to $100 \mathrm{~nm}$ with overall negative surface charge. XRD and FTIR analysis of drug-loaded CACNP have shown that drugs loaded within the nanoparticles maintained their crystallinity and functionality, respectively, within the nanoparticle as well as demonstrating effective loading of the drug. The colloidal stability of 
CACNP was investigated by Danmaigoro et al. (2017). They reported the stability of CACNP maintained in aqueous solvent at $\mathrm{pH} 7.9$ for 5 months at $50{ }^{\circ} \mathrm{C}$. The stability was attributed to stability of aragonite polymorph of calcium carbonate. The physiochemical properties of CACNP are summarized in Table 1.

Nonetheless, CACNP have exhibited promising potential as targeting nano-sized carriers against cancer cells. CACNP has also been used in osteoporosis therapy and hormonal delivery (Jaji 2017) as well as scaffolds for bone repair and tissue engineering (Bakar et al. 2011; Mahmood et al. 2017a, b). The pH-sensitive characteristic of CACNP provide a possibility of targeting cancer cells and controlled delivery of anticancer drugs. The sustainability of drug delivery as a result of the slow degradation of $\mathrm{CaCO}_{3}$ nanoparticles combined with potential to specifically target cancer cells, which results from their prospect to be functionalized with targeting compounds, are key features. Surface functionalization of $\mathrm{CaCO}_{3}$ nanoparticle opens a new perspective to actively target cancer cells or cancer stem cells. This combination leads to targeted and effective drug delivery for cancer diagnosis and treatment (Maleki Dizaj et al. 2015; Dizaj 2019; Abd Ghafar et al. 2017).

Table 1 Summary of physiochemical properties of cockle shell-derived calcium carbonate nanoparticles

\begin{tabular}{|c|c|c|c|c|c|}
\hline Mode of CACNP preparation & $\begin{array}{l}\text { XRD } \\
\text { pattern }\end{array}$ & $\begin{array}{l}\text { Encapsulation } \\
\text { efficiency (\%)/ } \\
\text { drug loaded }\end{array}$ & $\begin{array}{l}\text { Size and shape } \\
\text { viewed with TEM }\end{array}$ & Zeta potential & References \\
\hline $\begin{array}{l}\text { Cockle shell dissolved } \\
\text { with hydrochloric } \\
\text { acid }+\mathrm{CaCl}_{2}+\mathrm{Na}_{2} \mathrm{CO}_{3}+\text { cal- } \\
\text { cination }\end{array}$ & Calcite & & 50-100 nm, & & Tram (2020) \\
\hline \multirow[t]{2}{*}{$\begin{array}{l}\text { Higher pressure homogenizer } \\
(\mathrm{HPH}) \text { microemulsion system }\end{array}$} & Aragonite & $\begin{array}{l}64-96 \% \text { doxoru- } \\
\text { bicin }\end{array}$ & $\begin{array}{l}\text { 12-30 nm rod- } \\
\text { shaped, pleomor- } \\
\text { phic }\end{array}$ & & $\begin{array}{l}\text { Kamba (2013), } \\
\text { Kamba et al. } \\
\text { (2013a) }\end{array}$ \\
\hline & & $\begin{array}{l}\text { 99.5\% ciprofloxa- } \\
\text { cin }\end{array}$ & $\begin{array}{l}11.93 \text { to } 22.12 \mathrm{~nm} \\
\text { spherical shaped, } \\
\text { pleomorphic }\end{array}$ & & $\begin{array}{l}\text { Isa et al. } \\
\text { (2016) }\end{array}$ \\
\hline $\begin{array}{l}\text { Cockle shell microparticles with } \\
\text { surfactant BS- } 12 \text { stirred at } 80^{\circ} \mathrm{C} \\
\text { for } 90 \text { min }\end{array}$ & Aragonite & $54 \%$ vancomycin & $\begin{array}{l}34 \pm 5-36 \pm 6 \mathrm{~nm} \\
\text { cubic shaped } \\
\text { pleomorphic }\end{array}$ & $-19.4 \pm 3.3 \mathrm{mV}$ & $\begin{array}{l}\text { Saidykhan } \\
\text { et al. (2016) }\end{array}$ \\
\hline $\begin{array}{l}\text { Cockle shell microparticles with } \\
\text { surfactant BS- } 12 \text { stirred at } 27{ }^{\circ} \mathrm{C} \\
\text { for } 2 \mathrm{~h}\end{array}$ & Aragonite & $\begin{array}{l}93.8 \% \text { to } 97 \% \\
\text { doxorubicin }\end{array}$ & $\begin{array}{l}29.7 \pm 5 \mathrm{~nm} \text {, spheri- } \\
\text { cal, pleomorphic }\end{array}$ & $-19.1 \pm 3.9 \mathrm{mV}$ & $\begin{array}{r}\text { Hamidu } \\
\text { (2019) }\end{array}$ \\
\hline Mechanical method & Aragonite & 58.9\% cytarabine & $\begin{array}{l}\text { Diameter ranging } \\
\text { from } 20 \text { to } 50 \mathrm{~nm} \text {, } \\
\text { oval, homogene- } \\
\text { ous, }\end{array}$ & $-11 \mathrm{mV}$ & Ghaji (2018) \\
\hline \multirow[t]{2}{*}{$\begin{array}{l}\text { Cockle shell microparticles with } \\
\text { surfactant BS- } 12 \text { stirred at } 27^{\circ} \mathrm{C} \\
\text { for } 2 \mathrm{~h}+\text { mechanical method }\end{array}$} & Aragonite & $\begin{array}{l}95 \% \text { to } 99 \% \\
\text { doxorubicin }\end{array}$ & $\begin{array}{l}24.9 \pm 4.07 \mathrm{~nm} \\
\text { spherical, homoge- } \\
\text { neous }\end{array}$ & $-21 \mathrm{mV}$ & $\begin{array}{l}\text { Danmaigoro } \\
\text { et al. (2017) }\end{array}$ \\
\hline & & $\begin{array}{c}32 \% \text { to } 99 \% \\
\text { curcumin }\end{array}$ & $\begin{array}{l}21.38 \pm 2.7 \mathrm{~nm} \text { spher- } \\
\text { ical, pleomorphic }\end{array}$ & $-18.7 \mathrm{mV}$ & $\begin{array}{l}\text { Mailafiya } \\
\text { (2019b) }\end{array}$ \\
\hline $\begin{array}{l}\text { Cockle shell microparticles with } \\
\text { surfactant BS- } 12 \text { stirred } 50^{\circ} \mathrm{C} \\
\text { for } 135 \text { min }+ \text { mechanical } \\
\text { method }\end{array}$ & Aragonite & Gold & $\begin{array}{l}35 \pm 16 \mathrm{~nm} \text {, spheri- } \\
\text { cal, pleomorphic }\end{array}$ & $-16.4 \pm 3.81 \mathrm{mV}$ & $\begin{array}{l}\text { Kiranda et al. } \\
\text { (2018) }\end{array}$ \\
\hline
\end{tabular}




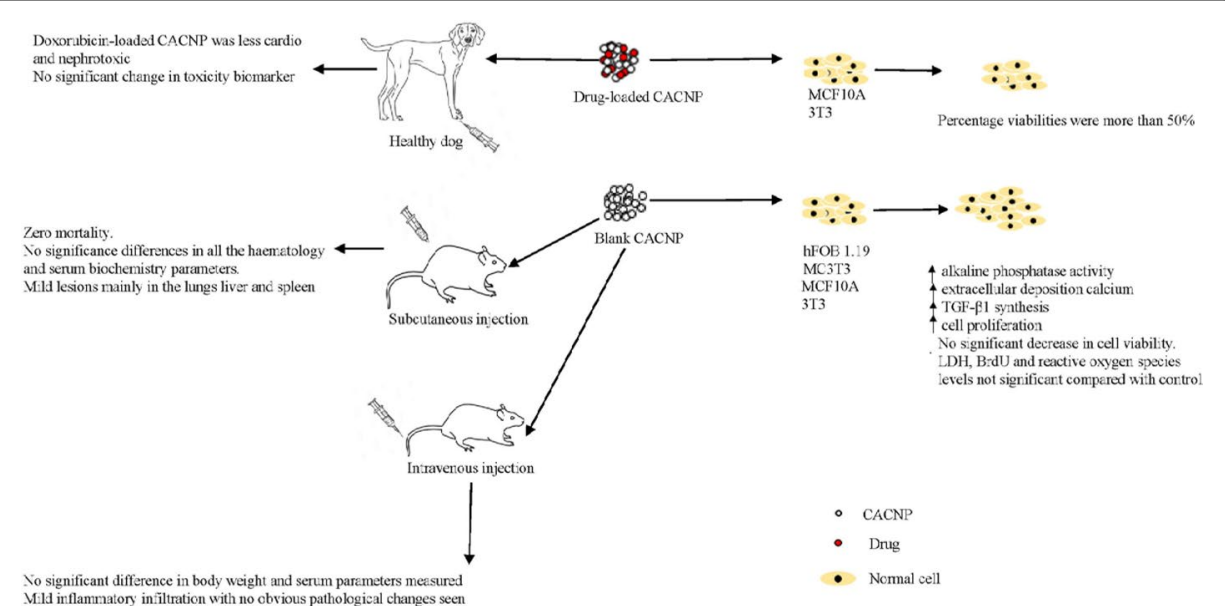

Fig. 2 In vitro and in vivo biocompatibility studies of cockle shell-derived calcium carbonate nanoparticle

CACNP as a drug delivery system

Drug loading is an important in achieving efficient nanomaterial drug delivery. Nanomaterial with high degree of loading capacity are principally required for drug administration. Due to the porosity of cockle shell-derived calcium carbonate nanoparticle, it is capable of loading different drugs irrespective of their hydrophobicity or surface charge. The application of CACNP as a drug delivery system is summarized in Table 1.

Cockle shell-derived calcium carbonate nanoparticles have successfully encapsulated cytarabine (Ghaji et al. 2018), docetaxel (Hammadi 2017a), doxorubicin (Danmaigoro et al. 2017; Kamba and Zakaria 2014; Fu 2017; Hamidu 2019), thymoquinone (Ibiyeye et al. 2020), parathyroid hormone (Jaji 2017), ketoprofen lysinate (Ghafar et al. 2017), ciprofloxacin (Isa et al. 2016), vancomycin (Saidykhan et al. 2016), oxytetracycline (Idris et al. 2019) and curcumin (Mailafiya 2019b). CACNP has been successfully loaded with both hydrophilic and hydrophobic drugs and their combination. CACNP has also been conjugated with gold as a nano-hybrid biomaterial for possible cancer imaging (Kiranda et al. 2018).

\section{Biocompatibility of CACNP}

Nano-sized materials are relatively unsafe. The characteristics of nano-sized materials are relatively different from larger particles of the same material. Safety of nano-sized materials have been shown to be dependent on nanoparticle morphology. Similarly, the size of nanoparticles is also important in determining biocompatibility. The decrease in particle size and larger surface area make them assimilate better in the body fluids and tissues thereby increasing their toxicity (Vishwakarma et al. 2010; Wolfram 2015). Gold nanoparticles of $1.4 \mathrm{~nm}$ size were found to be toxic, while $15 \mathrm{~nm}$ was not toxic at a concentration as high as 100-fold increase (Pan et al. 2007). CACNP size range may contribute to its safety. Unlike other nanoparticles, CACNP have shown no cytotoxic effect in normal cells and in in vivo studies (Fig. 2). CACNP has been shown to be safe on MCF10A, 3T3 mouse fibroblast cells, MC3T3 E-1 osteoblast cells, hFOB 1.19 human foetal osteoblastic cells (Kamba and Zakaria 2014; Fu 2017; Ibiyeye et al. 2020; Kiranda et al. 2018; Kamba et al. 2013a, 2014a; Hammadi 2017b). 
Hammadi et al. (2017a) recorded the cell viability of MCF10A to be more than $90 \%$ at a concentration of $1000 \mu \mathrm{g} / \mathrm{ml}$. Ibiyeye et al. (2019) also recorded cell viability of $80 \%$ when MCF10A and 3T3 were exposed to a concentration of $1000 \mu \mathrm{g} / \mathrm{ml}$ of CACNP. About $60 \%$ cell viability was observed in $3 \mathrm{~T} 3$ cells when exposed to gold-CACNP hybrid nanoparticle at $100 \mu \mathrm{g} / \mathrm{ml}$ concentration. On the other hand, $25 \mu \mathrm{g} / \mathrm{ml}$ of gold-CACNP increased 3T3 viability (Kiranda et al. 2018). Idris et al. observed the percentage cell viability of NIH3T3 cells to be $82.7 \%$ after $72 \mathrm{~h}$ treatment with $100 \mu \mathrm{g} / \mathrm{ml}$ CACNP. Kamba et al. (2013a) researched the effect of CACNP (0 to $400 \mu \mathrm{g} / \mathrm{ml}$ ) on NIH 3T3 cell line using various assays including MTT, LDH, BrdU and reactive oxygen species level. No significance differences was observed in all the parameters measured when compared with control. The percentages cell viability were $92 \%$ and $85 \%$ at concentrations of 200 and $400 \mu \mathrm{g} / \mathrm{ml}$, respectively (Ibiyeye et al. 2019).

Kamba and Zakaria (2014) evaluated the response of $200 \mu \mathrm{g} / \mathrm{ml}$ of CACNP on hFOB 1.19 and MC3T3 E1 osteoblast cells for 1 to 3 days. Increase in cell proliferation was noticed for both cells. The alkaline phosphatase activity of these cells increased significantly over time. Both cells produced significant amounts of intracellular protein when compared with the control. hFOB 1.19 and MC3T3 E-1 cells cultured with CACNP showed increase in extracellular deposition calcium when compared with control. A significant increase in TGF- $\beta 1$ synthesized by hFOB 1.19 and MC3T3 E-1 cells was observed when compared with control as well as increased production of VEGF in a time-dependent manner. Kamba and Zakaria concluded that CACNP encourage osteoblast differentiation and advance osteo-integration processes. Fu et al. (2017) noticed that when the hFOB 1.19 human foetal osteoblastic cells were exposed to high concentrations of CACNP at $500-1000 \mathrm{mg} / \mathrm{ml}$, the cell viability percentages were greater than 70\% (Fu 2017). CACNP and parathyroid hormone-loaded CACNP increased hFOB 1.19 cell proliferation best at 24 and 48 -h time periods, whereas parathyroid hormone-loaded CACNP has the highest cell viability at the 72-h period (Jaji 2017). Jaji (2017) concluded that CACNP is a facilitator of osteoblast proliferation and an efficient nanocarrier for sustained release of parathyroid hormone (Jaji 2017). Ghafar et al. (2017) analysed the cytotoxicity of surface-functionalized CACNP and CACNP without surface modification on hFOB 1.19. The percentage cell viability of surface-functionalized CACNP (90.1\%) was higher compared with CACNP without surface modification (79.5\%) at a dose $1000 \mu \mathrm{g} / \mathrm{ml}$. Surface modification of CACNP was observed to improve biocompatibility of CACNP (Ghafar et al. 2017).

Safety of CACNP have been demonstrated in vivo (Jaji et al. 2017; Chunyan et al. 2019). Jaji et al. (2017) evaluated the single and repeated subcutaneous dose of CACNP in SD rats. A single subcutaneous dose of $29,500 \mathrm{mg} / \mathrm{m}^{2}$ was given and closely monitored for 14 days. Also, 28 days repeated doses of 59,590 and $5900 \mathrm{mg} / \mathrm{m}^{2}$ of CACNP were studied. Zero mortality was documented at the end of both studies. The $59 \mathrm{mg} /$ $\mathrm{m}^{2}$-dose group showed no significance differences in all the haematology and serum biochemistry parameters measured when compared with the control while there were significance differences in almost all parameters for $5900 \mathrm{mg} / \mathrm{m}^{2}$ dose group. The $59 \mathrm{mg} / \mathrm{m}^{2}$ and $590 \mathrm{mg} / \mathrm{m}^{2}$-dose groups showed mild lesions mainly in the lungs liver and spleen. Single-dose $29,500 \mathrm{mg} / \mathrm{m}^{2}$ and $5900 \mathrm{mg} / \mathrm{m}^{2}$-dose group showed severe lesions in major organs. Jaji et al. concluded that $59 \mathrm{mg} / \mathrm{m}^{2}$ marked the safety margin of CACNP in SD 
rats. Chunyan et al. (2019) administered intravenous dose of $0,30 \mathrm{mg} / \mathrm{kg}, 60 \mathrm{mg} / \mathrm{kg}$ and $120 \mathrm{mg} / \mathrm{kg}$ CACNP to SD rats daily for 14 days. Two mortalities were recorded in $120 \mathrm{mg} / \mathrm{kg}$ group. There was no significant difference in body weight and serum parameters measured in all treatment groups compared with control. The histological changes observed in intravenous administration of $30 \mathrm{mg} / \mathrm{kg}$ CACNP include mild inflammatory infiltration with no obvious pathological changes seen while the $60 \mathrm{mg} / \mathrm{kg}$ and $120 \mathrm{mg} /$ $\mathrm{kg}$ groups showed obvious histological changes in main organs.

The safety of drug-loaded CACNP has been evaluated in non-neoplastic cells and healthy dogs (Ibiyeye et al. 2019; Danmaigoro 2018; Idris 2020). Ibiyeye et al. (2019) observed the cell viability of doxorubicin-loaded CACNP, thymoquinone-loaded CACNP and combined doxorubicin-thymoquinone-loaded CACNP on 3T3 and MCF10A. The percentage viabilities were more than $50 \%$ at 24,48 and $72 \mathrm{~h}$ after treatment for both cells. Danmaigoro (2018) evaluated the effects of repeated intravenous administration of doxorubicin-loaded CACNP on healthy dogs. Dogs were administered 5 cycles of doxorubicin-loaded CACNP $50 \mathrm{mg} / \mathrm{m}^{2}$ (high dose), $30 \mathrm{mg} / \mathrm{m}^{2}$ (clinical dose) and $20 \mathrm{mg} / \mathrm{m}^{2}$ (low dose) every 3 weeks. $30 \mathrm{mg} / \mathrm{m}^{2}$ and $20 \mathrm{mg} / \mathrm{m}^{2}$ treatment doses did not show any significant change in toxicity biomarker when compared with the control. Doxorubicin-loaded CACNP was less cardio and nephrotoxic at $50 \mathrm{mg} / \mathrm{m}^{2}$ dose when compared to dogs given equivalent free doxorubicin. The cytotoxicity of oxytetracyclineloaded CCANP and free oxytetracycline was evaluated in NIH3T3 cells for $72 \mathrm{~h}$. The percentage cell viability of oxytetracycline-loaded CACNP (75.5\%) was higher compared to free oxytetracycline $(66.0 \%)$ at $100 \mu \mathrm{g} / \mathrm{ml}$. Loading oxytetracycline into CACNP was observed to increase the biocompatibility of oxytetracycline (Idris 2020).

\section{Application of drug-loaded CACNP on cancers}

Nano-sized particles with diameters less than $600 \mathrm{~nm}$ as the advantage of enhanced permeation and retention effect at the site of cancerous tissues which facilitates the concentration of drugs in tumour environment. Moreover, calcium carbonate nanoparticles have unique liquid-phase characteristics which enable it to be stable at physiologic; in acidic $\mathrm{pH}$ they disintegrate. This property has been exploited to deliver drug-loaded CACNP to cancer environment and intracellular lysosome where they disintegrate releasing their constituents (Dizaj 2015). Electrostatic interactions between the negatively charged CACNP and the cancer cell membrane are of great biological importance. The adhesion of negatively charged nanoparticles to the cell membrane exerts a strong influence on the structure of the membranes by formation of a high-density domain of lipid tails, this facilitates their internalization into cancer cells via endocytosis (Behzadi 2017). These account for CACNP cytotoxicity. The cytotoxicity of drug-loaded CACNP (Table 2) has been demonstrated on different breast cancer cell lines (Hammadi 2017a, b; Kamba and Zakaria 2014; Kiranda et al. 2018; Kamba et al. 2013a, 2014b; Ibiyeye et al. 2019), osteoblastic and human osteogenic cell lines (Jaji 2017; Kamba and Zakaria 2014; Fu 2017; Kamba et al. 2013b), human leukemic cells (Ghaji 2018) and breast cancer enriched mammosphere (Ibiyeye and Zuki 2020). Drug-loaded CACNP was also demonstrated in breast cancer breast-bearing Balb/C mice (Hammadi 2018), murine xenograft leukemic model (Ghaji 2018), orthotopic osteosarcoma bearing rats (Fu 2018), and in evaluating the toxicity effects of repeated dose of doxorubicin loaded CACNP in 
Table 2 Summary of drug-loaded CACNP and their outcomes in cancer cells

\begin{tabular}{|c|c|c|}
\hline Drug loaded into CACNP & Response & References \\
\hline \multirow[t]{6}{*}{ Doxorubicin } & $\begin{array}{l}\text { Doxorubicin-loaded CACNP was effective in killing MCF-7 } \\
\text { and MDB } 231 \text { compared to free doxorubicin in a time- } \\
\text { dependent manner }\end{array}$ & $\begin{array}{l}\text { Kamba et al. (2013a, } \\
\text { Kamba et al. (2014b) }\end{array}$ \\
\hline & $\begin{array}{l}\text { Sensitivity of MCF-7 cell to free doxorubicin and doxoru- } \\
\text { bicin-loaded CACNP was time dependent }\end{array}$ & Hamidu (2019) \\
\hline & $\begin{array}{l}\text { Doxorubicin-loaded calcium carbonate nanoparticle } \\
\text { caused death of MG } 63 \text { cell by induction of apoptosis. } \\
\text { Induction of apoptosis was by up-regulation of p53, } \\
\text { Bax and caspases } 3,8 \text { and } 9 \text { and down-regulation of } \\
\text { the } \mathrm{BCl}-2 \text { protein }\end{array}$ & Kamba et al. (2013b) \\
\hline & $\begin{array}{l}\text { Doxorubicin-loaded CACNP showed a similar reduction } \\
\text { in cell viability as free doxorubicin in a concentration } \\
\text { and time-dependent manner }\end{array}$ & $\mathrm{Fu}(2017)$ \\
\hline & $\begin{array}{l}\text { Doxorubicin-loaded CACNP significantly reduced } \\
\text { osteosarcoma tumour volume and doxorubicin-related } \\
\text { cardiotoxicity in osteosarcoma bearing rats }\end{array}$ & Fu (2018) \\
\hline & Partial response and progressive canine RECIST response & Danmaigoro (2019) \\
\hline \multirow[t]{2}{*}{ Doxorubicin, thymoquinone } & $\begin{array}{l}\text { Doxorubicin-thymoquinone-loaded CACNP was the } \\
\text { most efficient in eliminating breast cancer cells at a } \\
\text { lower dose of doxorubicin and thymoquinone }\end{array}$ & Ibiyeye et al. (2019) \\
\hline & $\begin{array}{l}\text { Doxorubicin-thymoquinone-loaded CACNP was most } \\
\text { effective among the loaded CACNP in inhibiting CSCs' } \\
\text { properties }\end{array}$ & Ibiyeye and Zuki (2020) \\
\hline Gold & $\begin{array}{l}\text { Gold-conjugated calcium carbonate nanoparticle } \\
\text { progressively decreased the percentage cell viability of } \\
\text { MCF-7 cells }\end{array}$ & Kiranda et al. 2018) \\
\hline \multirow[t]{3}{*}{ Docetaxel } & $\begin{array}{l}\text { Free docetaxel and docetaxel-loaded CACNP revealed a } \\
\text { progressive reduction in percentage viability of MCF-7 } \\
\text { cancer cells in a dose and time-dependent manner }\end{array}$ & Hammadi (2017a) \\
\hline & $\begin{array}{l}\text { Docetaxel-loaded CACNP and free docetaxel has similar } \\
\text { anticancer effects on } 4 \mathrm{~T} 1 \text { cells }\end{array}$ & Hammadi (2017b) \\
\hline & $\begin{array}{l}\text { Tumour volume, organ weight, tumour inhibition rate, } \\
\text { and tumour metastatic score were significantly low- } \\
\text { ered in breast cancer bearing docetaxel-loaded CACNP } \\
10 \mathrm{mg} / \mathrm{kg} \text { Balb/C mice. group }\end{array}$ & Hammadi (2018) \\
\hline Cytarabine & $\begin{array}{l}\text { Cytarabine-loaded calcium carbonate nanoparticle sig- } \\
\text { nificantly ameliorated the cancer effect in major organs } \\
\text { of leukaemia-bearing SCID mice }\end{array}$ & Ghaji (2018) \\
\hline
\end{tabular}

healthy (Danmaigoro 2018) and tumour bearing dogs (Danmaigoro 2019). The effects of drug-loaded CACNP on various cancers (Fig. 3) are discussed below.

\section{Application of drug-loaded CACNP on breast cancer}

Kamba et al. (2013a, 2014b) evaluated the effect of free doxorubicin and doxorubicin-loaded CACNP on MCF-7 and MDB 231 breast cancer cell line. MTT, neural red, and lactate dehydrogenase colorimetric assays revealed higher toxicity of doxorubicin-loaded CACNP and effective cells killing compared to free doxorubicin in a time-dependent manner. Result of MCF-7 TUNEL assay verified that most of the cells undergoes apoptosis by internucleosomal fragmentation of genomic DNA (Kamba et al. 2014b). A significant increase in the amount of fragmented DNA was observed from 24 to $72 \mathrm{~h}$. Time and dose-dependent increase in Bax, cytochrome $\mathrm{C}$ and caspase-3 protein expression were observed (Kamba et al. 2013a, 2014b). Cell clumping, apoptotic bodies and membrane blebbing were apparent in the scanning electron 


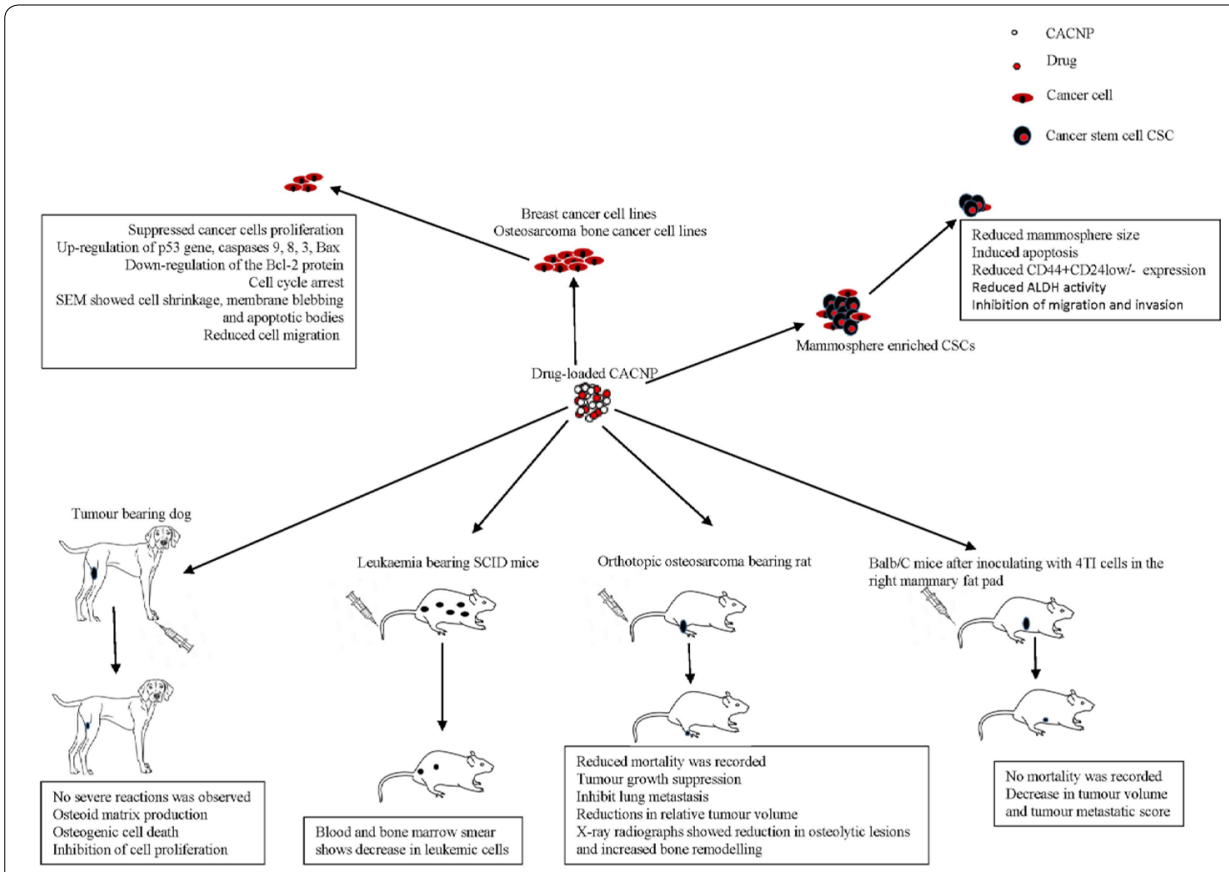

Fig. 3 Effects of drug-loaded CACNP in cancer in vitro and in vivo studies

microscope (SEM) analysis (Kamba et al. 2014b). Hamidu also evaluated free doxorubicin and doxorubicin-loaded CACNP on MCF-7 (Hamidu 2019). MCF-7 cells were more sensitive to free doxorubicin compared with doxorubicin-loaded CACNP at $24 \mathrm{~h}$ and $48 \mathrm{~h}$ treatment duration, while at $72 \mathrm{~h}$, cells were more sensitive to doxorubicin-loaded CACNP compared with free doxorubicin. The SEM findings were as described by Kamba et al. (2013a).

Gold-CACNP hybrid nanoparticle cytotoxicity studies on MCF7 revealed progressive decrease in percentage cell viability as the dose of increase from 0 to $100 \mu \mathrm{g} / \mathrm{ml}$ (Kiranda et al. 2018). Free docetaxel and docetaxel-loaded CACNP revealed a progressive reduction in percentage viability of MCF-7 cancer cells in a dose- and timedependent manner (Hammadi 2017a). MCF-7 was observed to be more sensitive to free docetaxel compared with docetaxel-loaded CACNP. At a maximum dose of $2 \mu \mathrm{g} /$ $\mathrm{ml}$, percentage viability of MCF-7 was $55 \%$ and $60 \%$ after exposure to free docetaxel and docetaxel-loaded CACNP, respectively, for $24 \mathrm{~h} ; 22 \%$ and $27 \%$, respectively, after 72-h treatment. Hammadi (2017a) stated that a lower amount of docetaxel released from the CACNP was responsible for the increased call viability as compared with free docetaxel. Less than $80 \%$ of the drug bound to the CACNP was released to the cells within the treatment period.

In vitro efficacy of docetaxel-loaded CACNP on $4 \mathrm{~T} 1$ mouse breast cancer cell line was carried out by Hammadi (2017b). MTT, Annexin V apoptotic assay, cell cycle analysis, scratch assay, scanning and transmission electron microscopy were carried out. The percentage cell viabilities at $24 \mathrm{~h}$ were above $50 \%$ at all concentrations of docetaxel and docetaxel-loaded CACNP. However, docetaxel-loaded CACNP group had a significant higher percentage cell viability compared with free docetaxel at 
$0.0625-0.5 \mu \mathrm{g} / \mathrm{ml}$ concentrations. At 48 and $72 \mathrm{~h}$, there was no significant difference in percentage cell viability of docetaxel and docetaxel-loaded CACNP groups. There was no significant difference in Annexin $\mathrm{V}$ assay in both free docetaxel and docetaxelloaded CACNP groups. Cell cycle arrest at subG0 and G2/M phases was noticed in both groups. SEM showed presence of cell membrane blebbing, while TEM showed nuclear fragmentation and vacuolation. Reduced cell migration was recorded in both free docetaxel and docetaxel-loaded CACNP groups with no significant difference. It was therefore concluded that docetaxel-loaded CACNP and free docetaxel has similar anticancer effects on 4T1 cells (Hammadi 2017b).

In vivo therapeutic study of docetaxel and docetaxel-loaded CACNP in Balb/C mice after inoculating with 4TI cells in the right mammary fat pad was carried out by Hammadi (Hammadi 2018). No mortality was recorded in docetaxel and docetaxelloaded CACNP group. Tumour volume, organ weight, tumour inhibition rate, and tumour metastatic score were significantly lower in docetaxel-loaded CACNP $10 \mathrm{mg} /$ kg group (Hammadi 2018).

Ibiyeye et al. (2019) evaluated the effect of doxorubicin and thymoquinone-loaded CACNP on MDA MB 231 breast cancer cell line. The free drugs were more effective in reducing the cell viability of MDA-MB-231 cells when compared with the drug-loaded CACNP except doxorubicin- thymoquinone-loaded CACNP which inhibited the growth of breast cancer cells than free doxorubicin/thymoquinone combination. Decrease in cell number was noted in all treatments as compared with control; this was most obvious in the doxorubicin-thymoquinone-loaded CACNP group. SEM revealed membrane blebbing, cell shrinkage and apoptotic bodies. Doxorubicin- thymoquinone-loaded CACNP treated group also showed cell membrane disruption. Annexin V apoptosis assay, doxorubicin-loaded CACNP was more effective in inducing apoptosis compared with free doxorubicin at $48 \mathrm{~h}$. At 24 and $72 \mathrm{~h}$ there was no significant difference in the induction of apoptosis in free doxorubicin and doxorubicin-loaded CACNP. Doxorubicin-thymoquinone-loaded CACNP has the highest percentage of apoptotic and necrotic cells. Doxorubicin-thymoquinone-loaded CACNP has the most percentage of in SubG0. Most of the treatments cause significant S-phase arrest at $72 \mathrm{~h}$. Free doxorubicin-thymoquinone was the most effective in inhibiting MDA-MB-231 cells metastasis. Nonetheless, doxorubicin-thymoquinone-loaded CACNP reduced cell metastasis more effectively than doxorubicin-loaded CACNP and thymoquinone-loaded CACNP. Ibiyeye et al. concluded doxorubicin-thymoquinone-loaded CACNP was the most efficient in eliminating breast cancer cells at lower dose of doxorubicin and thymoquinone (Ibiyeye et al. 2019).

\section{Application of drug-loaded CACNP on breast cancer stem cells}

Ibiyeye and Zuki (Ibiyeye and Zuki 2020) generated MDA MB231 3D cancer stem cells enriched mammosphere and the influence of combined doxorubicin-thymoquinoneloaded CACNP as well as single loaded drugs and free drugs was evaluated. Cancer stem cells were sensitive to doxorubicin-loaded CACNP and doxorubicin-thymoquinone-loaded CACNP and more resistance to free doxorubicin and doxorubicin-thymoquinone. Doxorubicin-thymoquinone-loaded CACNP also induced apoptosis in the CSCs compared to single drug-loaded CACNP. Free doxorubicin-thymoquinone 
and doxorubicin-thymoquinone-loaded CACNP had the smallest size mammospheres compared with control after day 10 of treatment. Scanning electron microscope showed cell shrinkage, poor spheroid formation, distortion of the spheroid architecture. Doxorubicin-thymoquinone-loaded CACNP treated mammosphere had the worse abnormal surface morphology compared to the other treatment. All treatment showed non-specific cell cycle arrest (Ibiyeye and Zuki 2020).

The effect of drug-loaded CACNP on CSCs ALDH activity, surface marker expression, self-renewal capacity and metastatic potential was also assessed by Ibiyeye and Zuki (2020). Doxorubicin-thymoquinone-loaded CACNP was the most effective in preventing CSCs self-renewal, thereby, selectively targeting CSCs. Doxorubicin-thymoquinone-loaded CACNP suppressed the expression of CD44+CD24low/- cancer stem cell surface marker the most at both days 3 and 10, while ALDH activity was reduced to zero percent and the percentage of viable cells was also reduced to $0.1 \%$ at day 10 . Ibiyeye and Zuki stated that high ALDH1 activity correlates with poor prognosis in breast cancer patients and has been associated with chemo/radio-resistance and poor prognosis, therefore, doxorubicin-thymoquinone-loaded CACNP can help reduce chemo/radioresistance and improve prognosis in breast cancer patients. Doxorubicin-thymoquinone-loaded CACNP was most effective among the loaded CACNP in reducing CSCs migration and invasion. The study concluded that doxorubicin-thymoquinone-loaded CACNP may serve as a potential curative strategy for the management of breast cancer recurrence and metastasis (Ibiyeye and Zuki 2020).

\section{Application of drug-loaded CACNP on bone cancer}

Kamba et al. (2013b) studied the in vitro delivery and controlled release of doxorubicinloaded CACNP in osteosarcoma bone cancer cells. MG 63 osteosarcoma bone cancer cells was treated with 0 to $2 \mu \mathrm{g} / \mathrm{ml}$ of free doxorubicin and doxorubicin-loaded CACNP for 24, 48 and $72 \mathrm{~h}$. It was observed that the cell inhibition rate was dependent on concentration and incubation periods. MG 63 cells was more sensitive to free doxorubicin at 24 and $48 \mathrm{~h}$. However, at $72 \mathrm{~h}$ it was observed that MG 63 cells was more sensitive to doxorubicin-loaded CACNP. Cell proliferation was evaluated with BrdU assay. Doxorubicin-loaded CACNP significantly suppressed MG 63 cells proliferation in a dose and time-dependent manner. Up-regulation of p53 gene, caspases 9, 8, 3, Bax and down-regulation of the Bcl-2 protein was observed in a concentration dependent manner. Kamba et al. postulated that the mechanisms by which doxorubicin-loaded CACNP cause cell death in MG 63 osteosarcoma bone cancer cells is by induction of apoptosis through upregulation of p53, caspases 9, 8, 3 and Bax and down-regulation of Bcl-2 (Kamba et al. 2013b).

$\mathrm{Fu}$ (2017) evaluated the effects of doxorubicin-loaded CACNP on the UMR-106 cells. The concentrations 0.125 to $1 \mathrm{mg} / \mathrm{ml}$ of free doxorubicin were more sensitive to UMR-106 cells. Fu et al. stated that this may be because free doxorubicin is immediately contacted with the cells, which may induce toxicity to the cells unlike the doxorubicin encapsulated in CACNP. Though at $2 \mathrm{mg} / \mathrm{ml}$ concentration, doxorubicin-loaded CACNP showed similar cell viability as free doxorubicin. Fu et al. noted that, doxorubicin-loaded CACNP showed a similar reduction in cell viability as free doxorubicin in a concentration and time-dependent manner. Morphological observations by light microscopy 
revealed decreased number of the cells, cell shrinkage, and detachment. Characteristic ultra-structural changes observed by SEM include microvilli disappearance, cell shrinkage, membrane blebbing and apoptotic bodies. TEM micrographs showed cell shrinkage, chromatin condensation. In addition, a large number of vesicles were noticed in the cytoplasm of cells treated with doxorubicin-loaded CACNP and few vacuoles containing doxorubicin-loaded CACNP coacervates. Doxorubicin and doxorubicin-loaded CACNP induced apoptosis in UMR-106 cells in a time-dependent manner. Doxorubicin-loaded CACNP induced cell cycle arrest, which was consistent with the mechanism of doxorubicin (Fu 2017).

$\mathrm{Fu}$ and colleagues (2018) induced osteosarcoma in orthotopic rat by injecting UMR106 cells into the tibia cavity. Osteosarcoma induced was at least pathological stage-III and radiographs revealed expansible osteolytic lesions. Five groups including control, osteosarcoma model group, $2 \mathrm{mg} / \mathrm{kg}$ free doxorubicin group and two groups of doxorubicin-loaded CACNP (2 mg and $1.5 \mathrm{mg}$ of corresponding doxorubicin $/ \mathrm{kg}$, respectively). There was no significant difference in the body weights gain in all treatment groups compared with control. However, there was significant difference in doxorubicin-loaded CACNP groups' body weight gain when compared to the free doxorubicin group. $50 \%$ of the rats in the free doxorubicin group died while only $16.7 \%$ mortality was recorded in $2 \mathrm{mg}$ doxorubicin-loaded CACNP group. Zero percentage mortality was recorded in $1.5 \mathrm{mg}$ doxorubicin-loaded CACNP group. Fu and colleague noted that doxorubicin-loaded CACNP is less toxic than the free doxorubicin. There was no significant difference in tumour growth suppression and reductions in the relative tumour volume in the doxorubicin-loaded CACNP groups and free doxorubicin group. However, there was significant difference when compared with osteosarcoma model group. $\mathrm{X}$-ray radiographs showed reduction in osteolytic lesions and increased bone remodelling in doxorubicin-loaded CACNP groups and free doxorubicin group. Serum creatine kinase increased significantly in the free doxorubicin group as compared with control group, however, a significant reduction in serum creatine kinase were found in the doxorubicin-loaded CACNP groups when compared with free doxorubicin. Control and osteosarcoma model groups showed normal myocardium with no pathologies seen. Free doxorubicin caused obvious cardiac tissue vacuolar degeneration, hypertrophy and disruption of cardiac muscle fibres, and myocardia fibrous necrosis. However, mild changes were seen in the doxorubicin-loaded CACNP groups. Fu et al. explained that CACNP ensured little to no release of doxorubicin from CACNP into the circulation which resulted in the absence of doxorubicin-related cardiotoxicity seen in doxorubicin-loaded CACNP groups. There was no significant changes in serum aspartate aminotransferase, alanine aminotransferase and alkaline phosphatase. Histological examination revealed an obvious reduction in the average tumour cell numbers in free doxorubicin and the doxorubicin-loaded CACNP groups. Both doxorubicin-loaded CACNP groups and free doxorubicin group effectively inhibit tumour growth, reduce tumour mass and inhibit lung metastasis. The study concluded that the doxorubicin-loaded CACNP can significantly reduce osteosarcoma tumour volume and doxorubicin-related cardiotoxicity. $1.5 \mathrm{mg}$ doxorubicin-loaded CACNP showed the comparable anticancer effect as $2 \mathrm{mg}$ doxorubicin-loaded CACNP, suggesting that CANP will allow reduction in chemotherapy doses (Fu 2018). 
Danmaigoro and colleagues (2019) explore the responses of doxorubicin-loaded CACNP on tumour bearing dogs, including osteosarcoma, in a single centred open clinical trial. No severe reactions to doxorubicin-loaded CACNP were observed. Partial response and progressive canine RECIST response were observed in the 15 weeks study period. Nonetheless, osteoid matrix production and osteogenic cell death and cell proliferation inhibition were recorded.

\section{Applications of drug-loaded CACNP of leukemic cells}

Ghaji (Ghaji 2018) studied CACNP as a cytarabine carrier against HL-60 human leukaemia cells and as anticancer therapy in leukaemia-bearing SCID mice. The IC50 values of cytarabine and cytarabine-loaded CACNP were $5 \mu \mathrm{g} / \mathrm{ml}$ and $2.5 \mu \mathrm{g} / \mathrm{ml}$, respectively at $72 \mathrm{~h} .2 .5 \mu \mathrm{g} / \mathrm{ml}$ cytarabine-loaded CACNP was more effective in inducing apoptosis than $5 \mu \mathrm{g} / \mathrm{ml}$ free cytarabine. SEM observations in both cytarabine and cytarabineloaded CACNP revealed disappearance of microvilli, membrane blebbing, cell shrinkage and apoptotic bodies. Blood and bone marrow smear, and histological examination of major organs revealed that CACNP significantly enhances the effects of cytarabine in leukaemia-bearing SCID mice (Ghaji 2018).

\section{Conclusions}

Cockle shell-derived aragonite calcium carbonate nanoparticles (CACNP) have shown high loading capacity for both hydrophilic and hydrophobic drugs. It is safe in non-neoplastic cells and drug-loaded CACNP have shown significant antitumor effect in cancers including breast, osteosarcoma, leukaemia, and breast cancer stem cells. More research is however required in the antitumor effect in other cancers like brain, lung, liver, pancreatic and more. This review also recommends more research in functionalization of CACNP to actively target cancer stem cells by decorating it with hyaluronic acid, anti CD44 antibody or any other subtract specific to various cancer stem cells. Molecular studies on the drug-loaded CACNP needs to be elaborated.

\section{Acknowledgements}

Not applicable.

Authors' contributions

$\mathrm{KMI}, \mathrm{ABZZ}$ and SBI wrote the manuscript. All authors read and approved the final manuscript.

Funding

Not applicable.

Availability of data and materials

Not applicable.

Ethics approval and consent to participate

Not applicable.

Consent for publication

Not applicable.

Competing interests

The authors declare no competing interest.

Received: 5 July 2020 Accepted: 27 September 2020

Published online: 07 October 2020 


\section{References}

Abd Ghafar SLM, ZobirHussein M, Zakaria ZAB. Synthesis and characterization of cockle shell-based calcium carbonate aragonite polymorph nanoparticles with surface functionalization. J Nanoparticles. 2017;2017:20-2.

Bakar ZA, Hussein BF, Mustapha NM. Cockle shell-based biocomposite scaffold for bone tissue engineering. Cells Biomater. 2011. https://doi.org/10.5772/21241.

Behzadi S, et al. HHS Public Access. Chem Soc Rev. 2017;46:4218-44.

Blanco E, Shen H, Ferrari M. Principles of nanoparticle design for overcoming biological barriers to drug delivery. Nat Biotechnol. 2015;33:941-51.

Boulos RA, et al. Spinning up the polymorphs of calcium carbonate. Sci Rep. 2014;4:1-6.

Chunyan S, Fu W, Zuki ABZ. Acute toxicity of cockle shell-derived calcium carbonate nanoparticles on rats. J Jilin Univ Ed. 2019:45:524-30.

Danmaigoro A, Selvarajah GT, Noor MHM, Mahmud R, Zakaria MZAB. Development of cockleshell (Anadara granosa) derived $\mathrm{CaCO} 3$ nanoparticle for doxorubicin delivery. J Comput Theor Nanosci. 2017;14:5074-86.

Danmaigoro A, et al. Toxicity and safety evaluation of doxorubicin-loaded cockleshell-derived calcium carbonate nanoparticle in dogs. Adv Pharmacol Sci. 2018;2018:1.

Danmaigoro A, et al. Toxicity and safety evaluation of doxorubicin-loaded cockleshell-derived calcium carbonate nanoparticle in dogs with solid tumours. Int J Nanotecnology. 2019;1189:730-49.

Dizaj SM, Barzegar-jalali M, Zarrintan MH, Adibkia K. Calcium carbonate nanoparticles. Potent Bone Tooth Disord. 2015;98:175-82

Dizaj SM, et al. Calcium carbonate nanoparticles as cancer drug delivery system. Expert Opin Drug Deliv. 2015;12:10.

Dizaj SM, et al. An update on calcium carbonate nanoparticles as cancer drug/gene delivery system. Expert Opin Drug Deliv. 2019;10:1

Fu W, et al. In vitro evaluation of a novel pH sensitive drug delivery system based cockle shell-derived aragonite nanoparticles ... In vitro evaluation of a novel pH sensitive drug delivery system based cockle shell-derived. J Exp Nanosci. 2017;12(1):166-87.

Fu W, et al. In vivo evaluation of anticancer efficacy of drug loaded cockle shell-derived aragonite nanoparticles. J Biomed Mater Res Part B Appl Biomater. 2018;12:1-10.

Ghafar SLMA, Hussein MZ, Rukayadi Y, Bakar MZA. Surface-functionalized cockle shell - based calcium carbonate aragonite polymorph as a drug nanocarrier. Nanotechnol Sci Appl. 2017:10:79-94.

Ghaji MS. Cockle shell-derived nano carrier for ara-c in the treatment of acute myeloid leukaemia. Berlin: University Putra Malaysia; 2018

Ghaji MS, Zakaria ZAB, Shameha AR, Noor MHM, Hazilawati H. Novel synthesis of nanoparticles from cockle shells via mechanical method for cytarabine drug release.J Comput Theor Nanosci. 2018:15:1128-36.

Ghiasi M, Malekzadeh A. Synthesis of $\mathrm{CaCO} 3$ nanoparticles via citrate method and sequential preparation of $\mathrm{CaO}$ and $\mathrm{Ca}(\mathrm{OH}) 2$ nanoparticles. Cryst Res Technol. 2012:478:471-8.

Hamidu A, et al. Modified methods of nanoparticles synthesis in $\mathrm{pH}$-sensitive nano-carriers production for doxorubicin delivery on MCF-7 breast cancer cell line. Int J Nanomedicine. 2019;14:3615-27.

Hammadi NI. Characterization, histological evaluation and efficacy of docetaxel-loaded cockle shell derived $\mathrm{CaCO} 3$ nanoparticles in vitro and in vivo. Malaysia: Universiti Putra; 2018.

Hammadi NI, et al. Formulation of a sustained release docetaxel loaded cockle shell-derived calcium carbonate nanoparticles against breast cancer. Pharm Res. 2017a;34:1193-203.

Hammadi NI, et al. Evaluation of in vitro efficacy of docetaxel-loaded calcium carbonate aragonite nanoparticles (DTXCaCO3NP) on 4T1 mouse breast cancer cell line. Vitr Cell Dev Biol Anim. 2017b;53:896-907.

Hanahan D, Weinberg RA. The hallmarks of cancer. Cell. 2000;100:57-70.

Hanahan D, Weinberg RA. Hallmarks of cancer: the next generation. Cell. 2011;144:646-74.

He M, Forssberg E, Wang Y, Han Y. Ultrasonication-assisted synthesis of calcium carbonate nanoparticles. Chem Eng Commun. 2005;192:1468-81.

Honary S, Zahir F. Effect of zeta potential on the properties of nano-drug delivery systems-a review (part 1). Trop J Pharm Res April J Cit. 2013a;12:255-255.

Honary S, Zahir F. Effect of zeta potential on the properties of nano-drug delivery systems - a review (part 2). Trop J Pharm Res. 2013b;12:265-265.

Horie M, et al. Chemico-biological interactions evaluation of cellular influences caused by calcium carbonate nanoparticles. Chem Biol Interact. 2014;210:64-766.

Ibiyeye KM, Zuki ABZ. Cockle shell-derived aragonite $\mathrm{CaCO} 3$ nanoparticles for co-delivery of doxorubicin and thymoquinone eliminates cancer stem cells. Int J Mol Sci. 2020;20:1-46.

Ibiyeye KM, Zuki AB, Nordin N, Ajat M. Ultrastructural changes and antitumor effects of doxorubicin/ thymoquinoneloaded CaCO3 nanoparticles on breast cancer cell line. Front Oncol. 2019:8:599.

Ibiyeye KM, Zuki AB, Zakaria NN, Ajat M. Combine drug delivery of thymoquinone-doxorubicin by cockle shell-derived pH sensitive aragonite $\mathrm{CaCO} 3$ nanoparticles. Nanosci Nanotechnol-Asia. 2020;10:524-39.

Idris SB, et al. Synthesis, characterization, and in vitro release of oxytetracycline loaded in pH-responsive CaCO3 nanoparticles. J Appl Pharm Sci. 2019;9:19-27.

Idris $\mathrm{SB}$, et al. In vitro cytotoxicity evaluation of oxytetracycline loaded cockle shell derived calcium carbonate aragonite nanoparticles. Nanosci Nanotechnol. 2020. https://doi.org/10.2174/2210681210999200420083144.

Isa T, Zakaria ZAB, Rukayadi Y, Hezmee MNM, Jaji AZ, Imam MU. Antibacterial activity of ciprofloxacin-encapsulated cockle shells calcium carbonate ( aragonite ) nanoparticles and its biocompatability in. Int J Mol Sci. 2016;17:713.

Jaji AZ, Abu Z, Zakaria B, Mahmud R. Safety assessments of subcutaneous doses of aragonite calcium carbonate nanocrystals in rats. J Nanopart Res. 2017. https://doi.org/10.1007/s11051-017-3849-z.

Jaji AZ, et al. Synthesis, characterization, and cytocompatibility of potential cockle shell aragonite nanocrystals for osteoporosis therapy and hormonal delivery. Nanotechnol Sci Appl. 2017;10:23-33.

Kamba AS, Zakaria ABZ. Osteoblasts growth behaviour on bio-based calcium carbonate aragonite nanocrystal. Biomed Res Int. 2014;2014:9. 
Kamba AS, et al. Synthesis and characterisation of calcium carbonate aragonite nanocrystals synthesis and characterisation of calcium carbonate aragonite nanocrystals from cockle shell powder ( Anadara granosa ). J Nanomater. 2013;2013:9.

Kamba AS, Ismail M, Azmi T, Ibrahim T, Zakaria ZAB. A pH-sensitive, biobased calcium carbonate aragonite nanocrystal as a novel anticancer delivery system. BioMed Res Int. 2013a;2013:10.

Kamba SA, Ismail M, Hussein-Al-Ali SH, Ibrahim TAT, Zakaria ZAB. In vitro delivery and controlled release of Doxorubicin for targeting osteosarcoma bone cancer. Molecules. 2013b;18:10580-98.

Kamba AS, Ismail M, Ibrahim TT, Zakaria ZAB. Biocompatibility of bio based calcium carbonate nanocrystals aragonite polymorph on NIH 3T3 fibroblast cell line. African J Tradit Complement Altern Med. 2014a;1:2.

Kamba AS, Ismail M, Ibrahim TAT, Zakaria ZAB, Gusau LH. In vitro ultrastructural changes of MCF-7 for metastasise bone cancer and induction of apoptosis via mitochondrial cytochrome $\mathrm{C}$ released by $\mathrm{CaCO} / \mathrm{Dox}$ nanocrystals. Biomed Res Int. 2014b;2014:391869.

Kezuka Y, Kawai K, Eguchi K, Tajika M. Fabrication of single-crystalline calcite needle-like particles using the aragonite-calcite. Miner Artic. 2017;7:133

Kiranda HK, Mahmud R, Abubakar D, Zakaria ZA. Fabrication characterization and cytotoxicity of spherical-shaped conjugated gold-cockle shell derived calcium carbonate. Nanopart Biomed Appl. 2018;13:1-10.

Lauth V, Maas M, Rezwan K. An evaluation of colloidal and crystalline properties of CaCO 3 nanoparticles for biological applications. Mater Sci Eng C. 2017;78:305-14.

Li L, Yang Y, Lv Y, Yin P, Lei T. Colloids and Surfaces B : Biointerfaces Porous calcite CaCO3 microspheres : preparation, characterization and release behavior as doxorubicin carrier. Colloids Surf B Biointerfaces. 2019;186:110720.

Mahmood SK, Razak ISA, Ghaji MS, Yusof LM, Mahmood ZK, Zakaria ZAB. In vivo evaluation of a novel nanocomposite porous 3D scaffold in a rabbit model: histological analysis. Int J Nanomed. 2017a;12:8587-98.

Mahmood SK, Zakaria MZAB, Razak ISB, Yusof LM, Jaji AZ, Hammadi NI. Preparation and characterization of cockle shell aragonite nanocomposite porous 3D scaffolds for bone repair. Biochem Biophys Reports. 2017b;10:237-51.

Mailafiya MM, et al. Cockle shell-derived calcium carbonate (aragonite) nanoparticles : a dynamite to nanomedicine. Appl Sci. 2019a;9:2897.

Mailafiya MM, et al. Evaluation of in vitro release kinetics and mechanisms of curcumin-loaded cockle shell-derived calcium carbonate nanoparticles Evaluation of in vitro release kinetics and mechanisms of curcumin-loaded cockle shell-derived calcium carbonate nanoparticles. 2019b. https://doi.org/10.15419/bmrat.v6i12.580.

Maleki DS, Barzegar-Jalali M, Zarrintan MH, Adibkia K, Lotfipour F. Calcium carbonate nanoparticles as cancer drug delivery system. Expert Opin. Drug Deliv. 2015;12:1649-60.

Mydin RB, Nadhirah I, Zahidi M, Ishak NN, Shaida N. Potential of calcium carbonate nanoparticles for therapeutic applications. Malaysian J Med Health Sci. 2018;14:201-6.

$\mathrm{Ni}$ M, Ratner BD. Differentiating calcium carbonate polymorphs by surface analysis techniques - an XPS and TOF-SIMS study. Surf Interface Anal. 2008;40:1356-61.

Pan Y, Neuss S, Leifert A, et al. Size-dependent cytotoxicity of gold nanoparticles. Small. 2007;3:1941-9.

Ranjan R, Narnaware SD. A novel technique for synthesis of calcium carbonate nanoparticles. Natl Acad Sci Lett. 2018. https://doi.org/10.1007/s40009-018-0704-4.

Render D, et al. Biomaterial-derived calcium carbonate nanoparticles for enteric drug delivery. J Nanomater. 2016;2016:3170248.

Saidykhan L, Bakar MZBA, Rukayadi Y, Kura AU, Latifah SY. Development of nanoantibiotic delivery system using cockle shell-derived aragonite nanoparticles for treatment of osteomyelitis. Int J Nanomed. 2016;11:661-73.

Sancho P, Barneda D, Heeschen C. Hallmarks of cancer stem cell metabolism. Br J Cancer. 2016;114:1305-12.

Tram NXT. Synthesis and characterization of calcite nano-particle derived from cockle shell for clinical application. ASEAN Eng J. 2020;10:49-544

Vishwakarma V, Samal SS, Manoharan N. Safety and risk associated with nanoparticles—a review. J Miner Mater Charact Eng. 2010;9:455-9.

Wolfram J, et al. Safety of nanoparticles in medicine. Curr Drug Targets. 2015;16:1671-81.

Xu X, Ho W, Zhang X, Bertrand N, Farokhzad O. Cancer nanomedicine: from targeted delivery to combination therapy. Trends Mol Med. 2015;21:223-32.

Yan X, Cui H, Qin Q, Tang W, Zhou X. Study on utilization of carboxyl group decorated carbon nanotubes and carbonation reaction for improving strengths and microstructures of cement paste. Nanomaterials. 2016;6:153.

\section{Publisher's Note}

Springer Nature remains neutral with regard to jurisdictional claims in published maps and institutional affiliations. 